\title{
Assessment of genetic diversity of landraces of Dendrocalamus hamiltonii using AFLP markers and association with biochemical traits
}

\author{
S.D. Waikhom ${ }^{1}$, S. Ghosh ${ }^{2}$, N.C. Talukdar ${ }^{1}$ and S.S. Mandi ${ }^{2}$ \\ ${ }^{1}$ Institute of Bioresource and Sustainable Development, Imphal, India \\ ${ }^{2}$ Bose Institute, Kolkata, India \\ Corresponding author: N.C. Talukdar \\ E-mail: nctalukdar@yahoo.com
}

Genet. Mol. Res. 11 (3): 2107-2121 (2012)

Received January 11, 2012

Accepted March 28, 2012

Published June 21, 2012

DOI http://dx.doi.org/10.4238/2012.June.21.1

\begin{abstract}
Fermented bamboo shoots are popular traditional food items of various ethnic groups of the northeastern India, especially in Manipur State. Dendrocalamus hamiltonii is an economically important bamboo species used to produce fermented bamboo shoots. We studied genetic variability of this bamboo species in Chandel and Imphal-East (commercial production districts), using AFLP molecular markers. Each of the selected primers detected polymorphisms and 1614 (95.8\%) were found to be polymorphic. Cluster analysis based on Dice similarity coefficients using UPGMA differentiated the populations into two major groups. Principal coordinate analysis based on the AFLP data clearly separated the populations according to their genetic diversity and antioxidant activity. Four primers were tested through multiple regression analysis to identify marker-trait association between AFLP data and biochemical attributes, i.e., antioxidant activity and total cyanide content. The 273 bp generated by EcoRI-AAG(Joe)/MseI-CTC showed high positive correlation with antioxidant activity $(\mathrm{r}=0.729, \mathrm{P}<0.01)$. The 396 bp generated by EcoRI-AAC(Ned)/MseI-CTG were negatively correlated with cyanide content $(\mathrm{r}=-0.694, \mathrm{P}<0.01)$. Thus, we found association of DNA markers with antioxidant activities and total cyanide
\end{abstract}


content. These results could be of use for the identification of superior genotypes with desirable traits.

Key words: AFLP marker; Antioxidant activity; Total cyanide content; Dendrocalamus hamiltonii; Multiple regression analysis

\section{INTRODUCTION}

Bamboo (Family: Poaceae; Sub-family: Bambusoideae) is a cash crop with multipurpose uses, including its young succulent shoots as a food, and contributes substantially to the rural economy in many Southeast Asian countries. Besides being a delicious vegetable, the bamboo shoots are also consumed in the form of fermented products in different parts of northeastern India. Edible bamboo shoots are harvested from forest annually (Bhatt et al., 2005a,b). In recent years, the consumption of bamboo shoots has spread to other countries, including the USA, Canada and Australia, due to the migration of ethnic people from Southeast Asian countries. This trend establishes export potential and increases rural economy potential, consequently increasing pressure on naturally occurring (forest) bamboo resources. Popularization of its cultivation may reduce dependence on sole forest resource and could thereby help meet the increasing requirement of edible bamboo shoots. This also requires molecular characterization of available bamboo germplasm (Ghosh et al., 2011) for species delimitation and to develop traits (edible/poisonous) related to DNA marker for selection of elite plant type for use in cultivation. Landraces (formation of a new species with sufficient variation that warrants its establishment) of a single conventional species may vary for desirable nutritional and medicinal properties as well as a lower content of undesirable toxic cyanogenic glycosides. Young succulent bamboo shoots of Dendrocalamus hamiltonii are consumed as a seasonal vegetable or in fermented forms, mostly by the ethnic communities of Manipur, a northeastern State. The major shoibum (fermented bamboo shoots) production centers of Manipur are located mainly in the hilly regions. The two traditional preparations, namely the Kwatha and Andro types, have high market demand and are produced by the ethnic communities of the Chandel and Imphal-East districts of Manipur (Jeyaram et al., 2009). Bamboo shoots of $D$. hamiltonii are preferred both as a vegetable and in shoibum preparation because of its low water content, good taste and other desirable properties for the fermentation process. An earlier study reported that even in the same geographical location, there is substantial variation within the $D$. hamiltonii growing in Nepal, with distinct varieties of this species recognized based on vegetative characters (Stapleton, 1994). So far, there has not been any research carried out to determine the molecular diversity and selective nutritional properties in the landraces of $D$. hamiltonii, occurring in the forests of two hill districts of Manipur. Molecular approaches have been used for assessing the genetic diversity of bamboos using RAPD and ISSR studies (Mishra and Sen-Mandi, 2004; Bhattacharya et al., 2006; Lalhruaitluanga and Prasad, 2009) and using amplified fragment length polymorphism (AFLP) studies (Garcia et al., 2004). A recent technique of coupling of AFLP with automated fluorescence dye-labeling has the advantage of enhanced resolution, precision and analytical power for large-scale genomic fingerprinting and higher reproducibility (Ghosh et al., 2011), compared to the conventional AFLP technique (Sciacca et al., 2010).

Cyanogenic glycoside, a poisonous compound in some genotypes of bamboo, produced from the precursor molecule taxiphyllin, is a defense mechanism against herbivores (Jones, 1998). Edible bamboos are known to contain antioxidants (Park and John, 2010). However, nutritive constituents such as amino acids, proteins, carbohydrates, minerals, vitamins, and phytosterols 
in shoots have been evaluated in a relatively large number of species (Srivastava, 1990; Shi and Yang, 1992; Nirmala et al., 2007). Evaluation for antioxidant properties and cyanogenic glycosides has also been carried out in a few species of Bambusa arundinacea Wild, Phyllostachys pubescens and P. nigra (Haque and Bradbury, 2002; Park and John, 2010).

Molecular markers, through their association with biochemical and functional traits, allow the establishment of trait-related DNA markers (Virk et al., 1996; Mishra and Sen-Mandi, 2004; Kar et al., 2008). Thus, this investigation was undertaken for the following purposes: i) to study the genetic relationships between $D$. hamiltonii populations using the AFLP technique with automated DNA sequencing, ii) to evaluate the total cyanide content and antioxidant activity in bamboo shoots, and iii) to determine the specific association between AFLP markers and biochemical traits such as antioxidant activity and total cyanide content for use in marker-assisted breeding.

\section{MATERIAL AND METHODS}

\section{Sampling}

Ten accessions of $D$. hamiltonii Nees \& Arn. ex Munro, locally known as "Unap", were collected from two districts, i.e., Imphal-East and Chandel of Manipur. Collection sites were chosen based on the distribution of $D$. hamiltonii and each accession of a population (Imphal-East and Chandel) was 10-50 km apart. Their name, geographical features and collection numbers are shown in Figure 1 and Table 1. The herbarium specimens of the collected samples were deposited with the Botanical Survey of India, Howrah, West-Bengal, India, for proper identification and storage. Leaf materials were collected for DNA isolation from clumps of 10 sites under study. Bamboo shoots of the 10 accessions for biochemical analysis were collected from three randomly chosen culms at each collection site.

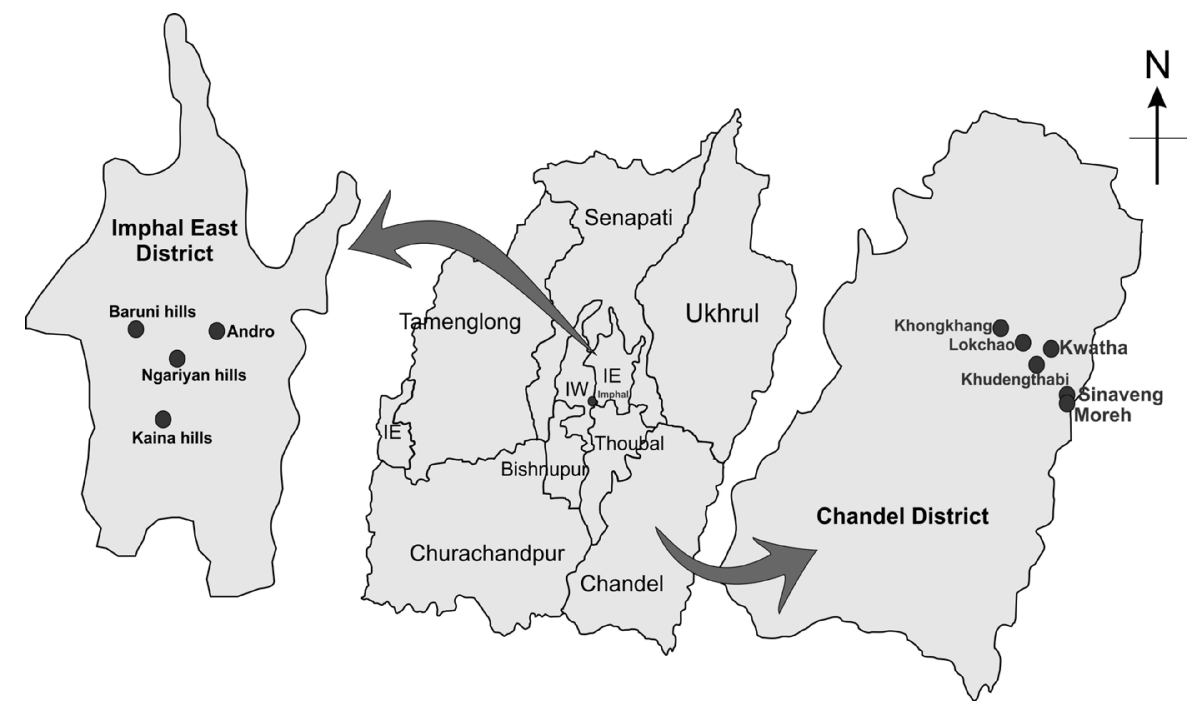

Figure 1. Geographical distribution of 10 accessions of Dendrocalamus hamiltonii occurring in Imphal East and Chandel districts of Manipur. 


\begin{tabular}{|c|c|c|c|c|c|c|c|}
\hline District & Collection sites & Name of accession ${ }^{\mathrm{a}}$ & Code & $\begin{array}{l}\text { Altitude } \\
(\mathrm{m})\end{array}$ & $\begin{array}{c}\text { Population } \\
\text { latitude }{ }^{\mathrm{b}}\left({ }^{\circ} \mathrm{N}\right)\end{array}$ & $\begin{array}{c}\text { Population } \\
\text { longitude }{ }^{\mathrm{b}}\left({ }^{\circ} \mathrm{E}\right)\end{array}$ & Collection No. \\
\hline \multirow[t]{6}{*}{ Chandel district } & Khongkhang & Unap-Khongkhang & U-CHP1 & 700 & $24^{\circ} 21^{\prime} \mathrm{N}$ & $94^{\circ} 12^{\prime} \mathrm{E}$ & $\mathrm{CH} / \mathrm{B} 02$ \\
\hline & Kudengthabi & Unap-Kudengthabi & U-CHP2 & 763 & $24^{\circ} 18^{\prime} \mathrm{N}$ & $94^{\circ} 15^{\prime} \mathrm{E}$ & $\mathrm{CH} / \mathrm{B} 11$ \\
\hline & Lokchao & Unap-Lokchao & U-CHP3 & 425 & $24^{\circ} 20^{\prime} \mathrm{N}$ & $94^{\circ} 14^{\prime} \mathrm{E}$ & $\mathrm{CH} / \mathrm{B} 12$ \\
\hline & Kwatha & Unap-Kwatha & U-CHP4 & 364 & $24^{\circ} 19^{\prime} \mathrm{N}$ & $94^{\circ} 16^{\prime} \mathrm{E}$ & $\mathrm{CH} / \mathrm{B} 013$ \\
\hline & Sinaveng & Unap-Sinaveng & U-CHP5 & 728 & $24^{\circ} 58^{\prime} \mathrm{N}$ & $94^{\circ} 40^{\prime} \mathrm{E}$ & $\mathrm{CH} / \mathrm{B} 002$ \\
\hline & Moreh & Unap-Moreh & U-CHP6 & 728 & $24^{\circ} 18^{\prime} \mathrm{N}$ & $94^{\circ} 16^{\prime} \mathrm{E}$ & $\mathrm{CH} / \mathrm{B} 001$ \\
\hline \multirow{4}{*}{ Imphal-East district } & Kaina hills & Unap-Kaina & U-IEP7 & 800 & $24^{\circ} 47^{\prime} \mathrm{N}$ & $94^{\circ} 02^{\prime} \mathrm{E}$ & IE/WS/001 \\
\hline & Baruni hills & Unap-Baruni & U-IEP8 & 1583 & $24^{\circ} 40^{\prime} \mathrm{N}$ & $94^{\circ} 02^{\prime} \mathrm{E}$ & $\mathrm{IE} / \mathrm{WS} / 002$ \\
\hline & Ngariyan hills & Unap-Ngariyan hills & U-IEP9 & 900 & $24^{\circ} 43^{\prime} \mathrm{N}$ & $94^{\circ} 02^{\prime} \mathrm{E}$ & IE/WS/004 \\
\hline & Andro & Unap-Andro & U-IEP10 & 770 & $24^{\circ} 44^{\prime} \mathrm{N}$ & $94^{\circ} 03^{\prime} \mathrm{E}$ & IE/WS/003 \\
\hline
\end{tabular}

${ }^{a}$ Accessions are named after local names (Unap) and its place of collections. The geographical locations of sampling sites are shown in Figure 1. ${ }^{b}$ Mean latitude and longitude of populations are calculated from latitude and longitude of all individuals of $D$. hamiltonii collected in that population.

\section{Morphological characterization}

Analysis was done using 35 morphological descriptors (11 culms, 13 culm-sheaths and 11 leaves) for each sample in triplicate. The morphological data were analyzed using NTSYS-pc version 2.2 (Rohfl, 2000), coupled according to Sneath and Sokal (1973), following the simple matching coefficient with SIMQUAL function for the generation of a similarity matrix. The best dendrogram was generated by coupling the unweighted pair-group method with arithmetric averages (UPGMA) (Sokal and Michener, 1958) and the SAHN function.

\section{DNA extraction and AFLP analysis}

DNA was extracted from young leaves using the N-cetyl-N, N, N-trimethylammonium bromide (CTAB) method described by Doyle and Doyle (1990) with modifications. DNA was quantified using the Spectrophotometer Nano Drop ${ }^{\mathrm{TM}}$ (Nano Technology). Quality assessment of extracted DNA was performed by agarose gel electrophoresis with ethidium bromide staining and a 1-kb DNA ladder (Novagen, Merck) as the DNA size marker.

The AFLP technique was performed on 500 ng genomic DNA with the AFLP Plant Mapping kit for average-sized genomes. The AFLP procedure followed manufacturer protocol. The method was based on Vos et al. (1995), but the primers were labeled with nonradioactive fluorescent dye. In all, 20 selective primer combinations were tested, and the four that gave good amplifications and showed polymorphisms were chosen. The combinations were EcoRI(Joe)-AAG/MseI-CTC, EcoRI(Ned)-ACC/MseI-CTG, EcoRI(Ned)-AAC/MseI-CTG, EcoRI(Joe)-ACG/MseI-CAG. Selective amplification was conducted on a Thermocycler (Applied Biosystems Veriti ${ }^{\mathrm{TM}}$, USA), according to the following program: $94^{\circ} \mathrm{C}$ for $2 \mathrm{~min} ; 10$ cycles of $94^{\circ} \mathrm{C}$ for $20 \mathrm{~s}, 66^{\circ} \mathrm{C}\left(-1^{\circ} \mathrm{C} /\right.$ cycle $)$ for $30 \mathrm{~s}$ and $72^{\circ} \mathrm{C}$ for $2 \mathrm{~min} ; 20$ cycles of $94^{\circ} \mathrm{C}$ for $20 \mathrm{~s}, 56^{\circ} \mathrm{C}$ for $30 \mathrm{~s}$ and $72^{\circ} \mathrm{C}$ for $2 \mathrm{~min}$, and $60^{\circ} \mathrm{C}$ for $30 \mathrm{~min}$ and $4^{\circ} \mathrm{C}$ for infinity. The samples were loaded onto a 6\% (29:1) polyacylamide gel on an ABI Prism 377 Sequencer (Applied Biosystems). An internal size standard (GS-500 ROX, Applied Biosystems) was included in each sample to facilitate fragment sizing, and the GeneScan Analysis 2.1 Software was used to estimate fragment size. Hereafter, the GeneScan scoring table was constructed and exported to 
Microsoft excel. Markers that failed in displaying good amplification in any of the individuals were excluded from further analysis.

\section{Cluster and principal coordinate analysis (PCA)}

Genetic similarities were calculated from the scoring matrix using the DICE coefficient (Dice, 1945) in the NTSYS pc version 2.2 software (Rohlf, 2000). Based on the distance matrix, cluster analysis was performed by the UPGMA of the same NTSYS software package. Furthermore, PCA was carried out based on the pairwise genetic similarity matrix using the DCENTER and EIGEN procedures of the NTSYS pc version 2.2 software.

\section{Antioxidant activity}

Thirty-day-old juvenile bamboo shoots of the $10 \mathrm{D}$. hamiltonii accessions were harvested and washed with distilled water after removal of all sheath coverings. Sliced pieces of $100 \mathrm{~g}$ were weighed out and boiled with $300 \mathrm{~mL}$ distilled water for $2 \mathrm{~h}$ at $100^{\circ} \mathrm{C}$ (Soxhlet extraction). The total extract was filtered through Whatman No. 6 filter paper. The filtrate was evaporated on a water bath at $100^{\circ} \mathrm{C}$, and the solid residue was stored in a refrigerator $\left(4^{\circ} \mathrm{C}\right)$ for further experiments. The scavenging effect of the extracts for DPPH (2, 2-diphenyl-1-picrylhydrazyl) radical was monitored according to the method of Mensor et al. (2001). One milliliter of $0.3 \mathrm{mM}$ DPPH ethanolic solution was added to each $3.0 \mathrm{~mL}$ of the samples with different concentrations of bamboo shoots extract. The mixtures were vortexed for $1 \mathrm{~min}$ and then left to stand at room temperature in the dark. After $30 \mathrm{~min}$, absorbance was read at $517 \mathrm{~nm}$ in a UVvisible spectrophotometer (UV-1700, Shimadzu). The scavenging activity of the DPPH radical was calculated using the following equation: Scavenging activity $(\%)=100 \times\left(\mathrm{A}_{\text {Control }}-\mathrm{A}_{\text {Sample }}\right)$ $/ \mathrm{A}_{\text {Control }}$, where $\mathrm{A}_{\text {Control }}$ is the absorbance of the control reaction (containing all reagents except the test extract) and $A_{\text {Sample }}$ is the absorbance of the test compound. The half-maximal inhibitory concentration $\left(\mathrm{IC}_{50}\right)$ was defined as the amount of extract required for $50 \%$ reduction of free scavenging activity. The $\mathrm{IC}_{50}$ values were obtained from the inhibition curves.

\section{Determination of total cyanide content using the picrate method}

Thirty-day-old juvenile bamboo shoots of $D$. hamiltonii harvested from the ground level were assayed for cyanide using the modified picrate method (Haque and Bradbury, 2002). Analyses were carried out on three portions (top, middle and bottom) obtained by cutting each shoot at equal distances. The standard curve for determination of HCN was obtained using $\mathrm{NaCN}$ solution. Five milliliters of alkaline picrate solution $(1.4 \mathrm{~g}$ picric acid in $2.5 \%$ $\mathrm{Na}_{2} \mathrm{CO}_{3}$ ) and $5 \mathrm{~mL} \mathrm{NaCN}$ solution $(181 \mathrm{mg} \mathrm{NaCN}$ in $1 \mathrm{~L}$ water to give $100 \mu \mathrm{g} \mathrm{HCN} / \mathrm{mL}$ concentrations) were heated together for $5 \mathrm{~min}$ in boiling water. Samples of 0.1, 0.2, 0.4, 0.6, 0.8, and $1 \mathrm{~mL}$ of the resultant $\mathrm{NaCN}$ alkaline picrate solution were placed in separate test tubes and made up to $5 \mathrm{~mL}$ with distilled water to give $5,10,20,30,40$, and $50 \mu \mathrm{g} \mathrm{HCN}$, respectively.

\section{Karl Pearson correlation coefficient and multiple regression analysis}

Correlations between parameters were examined using the Karl Pearson correlation 
method. The association between AFLP markers and the quantitative traits was estimated through stepwise multiple regression analysis (MRA), where each quantitative trait was treated as a dependent variable, while the AFLP markers were treated as independent variables. The analysis was based on the model: $\mathrm{Y}=\mathrm{a}+\mathrm{b}_{1} \mathrm{~m}_{1}+\mathrm{b}_{2} \mathrm{~m}_{2}+\ldots \ldots+\mathrm{b}_{\mathrm{j}} \mathrm{m}_{\mathrm{j}}+\ldots \ldots \mathrm{b}_{\mathrm{n}} \mathrm{m}_{\mathrm{n}}+\mathrm{d}+\mathrm{e}$, which related the variation in the dependent variable ( $Y=$ accession for a quantitative trait) to a linear function of the set of independent variables $m j$, representing AFLP markers. The $b j$ terms are the partial regression coefficients that specify the empirical relationships between $Y$ and $m j ; d$ represents between-accession residual, which is left after regression, and $e$ is the random error of Y, which includes environmental variation (Virk et al., 1996; Kar et al., 2008). To select independent variables for the regression equation, $\mathrm{F}$ values with 0.045 and 0.099 probabilities were used to enter and remove, respectively (Affifi and Clark, 1984). All analyses were performed using the same SPSS software package. $\mathrm{R}^{2}$ is the correlation coefficient. Selected markers were further tested with linear curve fitting, using linear models for confirming the significance of $\beta$-statistics for each band identified by MRA. Beta can be defined as standardized regression coefficient $=\mathrm{BSx} / \mathrm{BSy}$, where $B$ is the regression coefficient or slope and $S x$ and $S y$ are the standard deviations of independent (x) and dependent (y) variables (Affifi and Clark, 1984; Kar et al., 2008; Ruan et al., 2009).

\section{RESULTS AND DISCUSSION}

\section{Morphological variation among populations of $D$. hamiltonii}

The UPGMA dendrogram based on morphological similarity values (simple matching coefficient) with a cophenetic value of 0.67 is presented in Figure 2. The dendrogram produced two groups. Accessions U-CHP1, U-CHP2, U-CHP3, and U-CHP4 belonging to the same population were observed to be morphologically close in the dendrogram. Interestingly, the U-CHP5 and U-CHP6 accessions were grouped with the other accessions of a population. Although, the morphological dendrogram generated from similarity or genetic distance matrices provided an overall pattern of variation as well as the degree of relatedness between accessions, variation in environmental conditions such as soil types, light, temperature, and moisture regime leads to different results when using morphological characters. Vegetative characters such as culm and culm sheath are the major criteria used by taxonomists for the identification of bamboo species (Ohrnberger and Goerrings, 1986) in the absence of floral characteristics. According to $\mathrm{Wu}$ (1962), classification based on vegetative characters poses a number of problems because vegetative characters are often environmentally influenced, which is not constant for systematic purposes. Hence, these observations emphasize the need for implementing molecular techniques such as DNA genetic markers for proper characterization of $D$. hamiltonii germplasm.

\section{Molecular characterization and assessment of genetic diversity with AFLP marker}

Among all primer combinations selected, four combinations were able to induce the highest polymorphism levels as well as a uniform distribution of peaks in the region analyzed (35-629 bp). The selected combinations of primers generated a total of 1684 peaks, of which $95.8 \%$ were polymorphic (Table 2 ). The level of polymorphism ranged from $92.04 \%$ 
(EcoRI-ACG(Joe)/MseI-CAG) to $100 \%$ (EcoRI-AAC(Ned)/MseI-CTG). The DICE similarity between accessions ranged from 0.152 (U-CHP4 vs U-IEP7) to 0.856 (U-CHP5 vs UCHP6), with an average similarity among all accessions of 0.454 . The UPGMA cluster analysis revealed that the 10 accessions were clustered into 2 groups (Figure 3). Group 1 consisted mainly of populations from the Imphal-East district with a mean similarity index ( $\mathrm{Si}$ ) of 0.592, while Group 2 contained populations from the Chandel district with a mean Si of 0.563. The selected primers used in this study gave a reasonable number of amplification products for the genetic diversity analysis of $D$. hamiltonii. Despite their drawback of being dominant markers, the major advantage of AFLPs is their capacity to generate a large number of markers compared to other molecular marker systems, making it an important tool for population genetic investigations. The results of this research demonstrated that a substantial level of genetic variation exists within $D$. hamiltonii accessions, indicating that fluorescence-based AFLP analysis is sensitive and reproducible for detecting such levels of variation. Thus, our findings provide guidance for future efficient use of these molecular methods in the genetic analysis of this bamboo species.

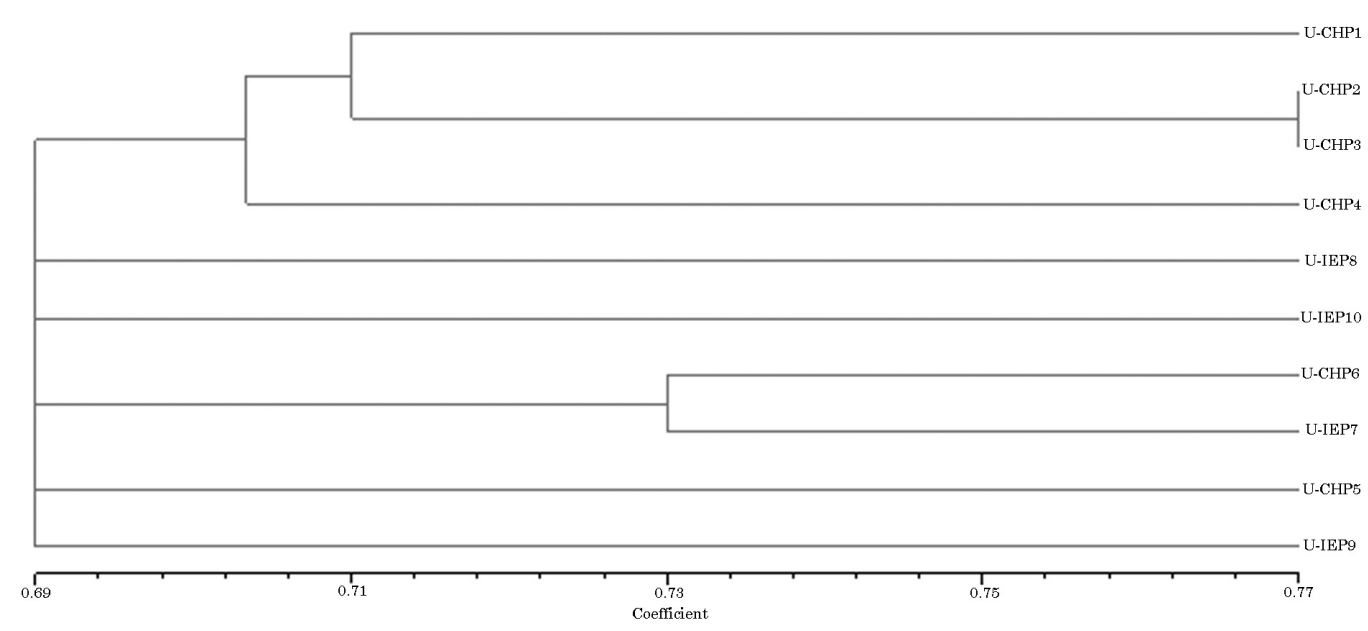

Figure 2. UPGMA dendrogram based on morphological data on 10 accessions of Dendrocalamus hamiltonii. Similarity values were calculated with the simple matching coefficient.

Table 2. Polymorphism within the 10 Dendrocalamus hamiltonii accessions obtained by AFLP markers using
selected primer combinations.
\begin{tabular}{lccc}
\hline Primer combinations & No. of scoreable peaks & No. of polymorphic peaks & Polymorphic peaks (\%) \\
\hline EcoRI-AAG(Joe)/MseI-CTC & 385 & 365 & 94.81 \\
EcoRI-ACG(Joe)/MseI-CAG & 377 & 347 & 92.04 \\
EcoRI-AAC(Ned)/MseI-CTG & 428 & 428 & 100.0 \\
EcoRI-ACC(Ned)/MseI-CTG & 494 & 474 & 95.95 \\
Total & 1684 & 1614 &
\end{tabular}




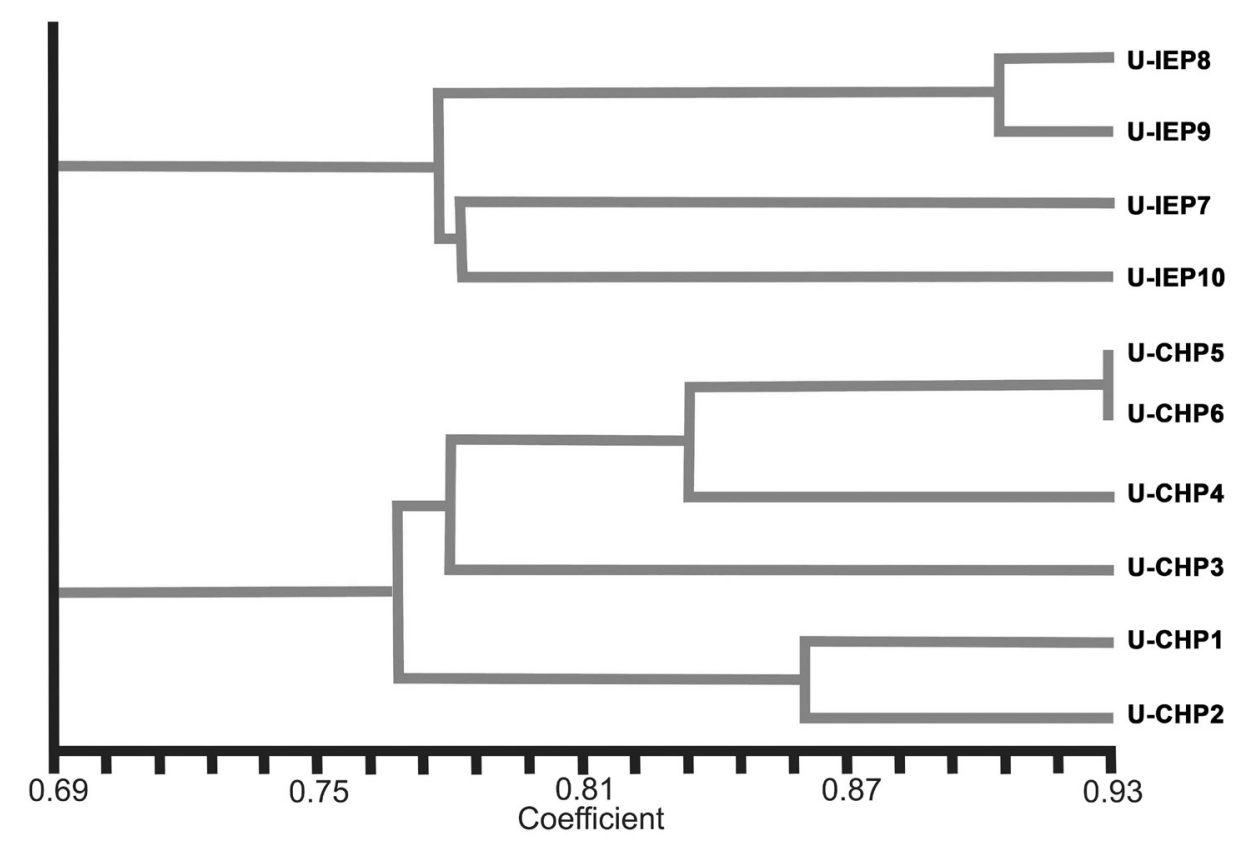

Figure 3. Dendogram of 10 accessions of Dendrocalamus hamiltonii resulting from a UPGMA cluster analysis based on DICE estimates of similarity obtained from 1684 AFLP peaks.

\section{Scavenging activity on DPPH radicals}

DPPH was used to determine the proton-radical scavenging action of the bamboo shoot extract since it possesses a proton free radical and shows a high level of sensitivity. Figure 4 shows the dose-response curve for the radical scavenging activity of a water extract of bamboo shoots (WEB) for the $10 \mathrm{D}$. hamiltonii accessions. A significant variation in terms of free radical scavenging activity of WEB was observed among accessions of $D$. hamiltonii (26.54-43.45\%). Strong DPPH activity of WEB at $400 \mu \mathrm{g} / \mathrm{mL}$ was observed in U-IEP8 (43.45\%), followed by U-IEP9 (38.9\%), while the lowest was obtained in U-CHP6 $(26.54 \%)$. While Table 3 depicts the calculated $\mathrm{IC}_{50}$, the concentration required for decreasing the initial $\mathrm{DPPH}$ concentration by $50 \%$. The $\mathrm{IC}_{50}$ was obtained by interpolation from linear regression analysis of data shown in Figure 4. The $\mathrm{IC}_{50}$ value of WEB in U-IEP8 was $0.114 \mathrm{mg} / \mathrm{mL}$ compared to that of ascorbic acid of $0.003 \mathrm{mg} / \mathrm{mL}$. A limited report is available on the antioxidant activity of bamboo shoot extracts, and most of the research has focused on the extracts of leaves and bamboo culms (Hu et al., 2000; Kweon et al., 2001). Park and Jhon (2010) showed that two cultivated edible bamboo species of Korea, P. pubescens and $P$. nigra, possessed strong antioxidant activity in their bamboo shoot extracts. The present study was the efforts for the elaborate research on the screening of scavenging activity of WEB on the DPPH free radicals of $D$. hamiltonii accessions grown in two districts of Manipur, the major production region of fermented bamboo shoots. Such wide variations in antioxidant activity have also been reported among genotypes of cultivars in various fruit species such as blueberry (Connor et al., 2005) and apple (Drogoudi et al., 2008). 


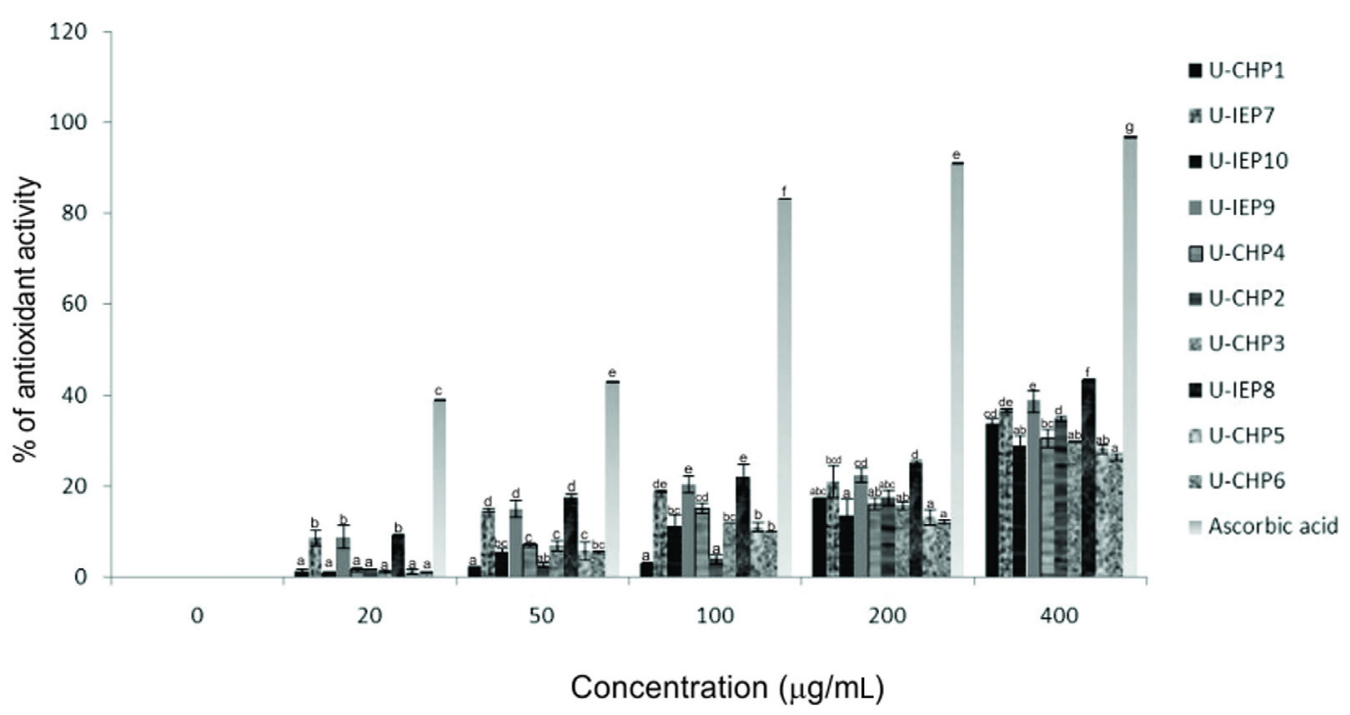

Figure 4. DPPH scavenging effect of water bamboo shoot extract of Dendrocalamus hamiltonii accessions. Different letters above the columns indicate statistically significant differences (linear regression analysis).

Table 3. Antioxidant capacity of hot water extract from fresh bamboo shoots of 10 accessions of Dendrocalamus hamiltonii by DPPH radical scavenging method.

\begin{tabular}{ccc}
\hline S1. No. & Name of populations & Antioxidant capacity $\left(\mathrm{IC}_{50}: \mathrm{mg} / \mathrm{mL}\right)$ \\
\hline 1 & U-CHP1 & $0.147 \pm 0.004^{\mathrm{cd}}$ \\
2 & U-CHP2 & $0.144 \pm 0.003^{\mathrm{cd}}$ \\
3 & U-CHP3 & $0.167 \pm 0.002^{\mathrm{de}}$ \\
4 & U-CHP4 & $0.163 \pm 0.01^{\mathrm{de}}$ \\
5 & U-CHP5 & $0.177 \pm 0.02^{\mathrm{ef}}$ \\
6 & U-CHP6 & $0.193 \pm 0.005^{\mathrm{f}}$ \\
7 & U-IEP7 & $0.139 \pm 0.004^{\mathrm{c}}$ \\
8 & U-IEP8 & $0.114 \pm 0.002^{\mathrm{b}}$ \\
9 & U-IEP9 & $0.130 \pm 0.008^{\mathrm{be}}$ \\
10 & U-IEP10 & $0.179 \pm 0.007^{\mathrm{ef}}$ \\
11 & Ascorbic acid & $0.003 \pm 0.001^{\mathrm{a}}$ \\
\hline
\end{tabular}

Amount of bamboo shoot extract required for $50 \%$ reduction of free radical scavenging activity. All experiments were replicated three times and results are reported as means \pm SD. Mean values followed by the same superscript letters do not differ significantly by the Duncan multiple range test $(\mathrm{P} \leq 0.05)$.

\section{Total cyanide content using the picrate method}

Total cyanide content of three portions, i.e., tip, middle and base in bamboo shoots of the 10 populations of $D$. hamiltonii are shown in Table 4 . The total cyanide levels were the highest at the tip and the lowest at the base of the bamboo shoot. The highest cyanide content in the middle portion was found in the U-CHP3 $(1123 \mathrm{ppm})$ and the lowest was obtained in U-IEP8 (940 ppm). There was a significant variation in total cyanide content in bamboo shoots among the accessions. Cyanogenesis is the ability of some plants to synthesize cyanogenic glycosides, which when enzymatically hydrolyzed, release hydrocyanic acid (HCN), 
also known as prussic acid (Harborne, 1993). There is strong evidence that cyanogenesis is one of the mechanisms that can serve the plant as a protective mechanism against predators such as herbivores (Jones, 1998). This probably explains the presence of high concentration of cyanide in the apical portions to protect the plant from pathogenic attack at immature stages. Wide variation in cyanogenesis within genotypes may be due to variation in both the production of cyanogenic glycosides themselves and the enzyme, which degrades them, depending on different physiological or ecological factors (Vetter, 2000). A couple of investigations have been carried out on total cyanide content in bamboo shoots of limited bamboo species, namely B. arundinacea Willd (Haque and Bradbury, 2002) and giant bamboo (Cathariostachys madagascariensis), important food plants of lemurs (Ballhorn et al., 2009). Hence, the present study aimed to determine the total cyanide content within genotypes of bamboo species.

Table 4. Total cyanide content (ppm) in bamboo shoots of the 10 Dendrocalamus hamiltonii accessions.

\begin{tabular}{lccc}
\hline Name of population & \multicolumn{3}{c}{ Total cyanide content $(\mathrm{ppm})$} \\
\cline { 2 - 4 } & Tip portion & Middle portion & Base portion \\
\hline U-CHP1 & $1816^{\mathrm{b}}$ & $1096^{\mathrm{ab}}$ & $677^{\mathrm{a}}$ \\
U-CHP2 & $1735^{\mathrm{b}}$ & $1035^{\mathrm{ab}}$ & $660^{\mathrm{a}}$ \\
U-CHP3 & $1858^{\mathrm{b}}$ & $1123^{\mathrm{b}}$ & $713^{\mathrm{a}}$ \\
U-CHP4 & $1753^{\mathrm{b}}$ & $1054^{\mathrm{ab}}$ & $660^{\mathrm{a}}$ \\
U-CHP5 & $1841^{\mathrm{b}}$ & $1061^{\mathrm{ab}}$ & $671^{\mathrm{a}}$ \\
U-CHP6 & $1785^{\mathrm{b}}$ & $1118^{\mathrm{b}}$ & $706^{\mathrm{a}}$ \\
U-IEP7 & $1724^{\mathrm{b}}$ & $1008^{\mathrm{ab}}$ & $677^{\mathrm{a}}$ \\
U-IEP8 & $1330^{\mathrm{a}}$ & $940^{\mathrm{a}}$ & $661^{\mathrm{a}}$ \\
U-IEP9 & $1717^{\mathrm{b}}$ & $994^{\mathrm{ab}}$ & $639^{\mathrm{a}}$ \\
U-IEP10 & $1727^{\mathrm{b}}$ & $1106^{\mathrm{ab}}$ & $691^{\mathrm{a}}$ \\
\hline
\end{tabular}

$\mathrm{ppm}=\mathrm{mg} \mathrm{HCN}$ equivalents $/ \mathrm{kg}$ bamboo shoots. All experiments were replicated three times. Values followed by the same superscript letters do not differ significantly by the Duncan multiple range test $(\mathrm{P} \leq 0.05)$.

\section{Correlation analysis}

The Karl Pearson correlation coefficients for different morphological and biochemical parameters are shown in Table 5. A strong negative correlation coefficient was observed between total antioxidant activity and total cyanide content $(\mathrm{r}=-0.98)$, which was significant at $\mathrm{P}<0.01$. Height of the culms showed a positive correlation with diameter $(\mathrm{r}=0.965, \mathrm{P}<$ $0.01)$, internodal length $(\mathrm{r}=0.831, \mathrm{P}<0.01)$ and total culm sheath length $(0.774, \mathrm{P}<0.01)$, and negatively correlated with breadth at the base of the culm sheath $(\mathrm{r}=-0.829, \mathrm{P}<0.01)$. Diameter was positively correlated with internodal length $(\mathrm{r}=0.732, \mathrm{P}<0.05)$ and total culm sheath length $(\mathrm{r}=0.748, \mathrm{P}<0.05)$, while negatively correlated with breadth at base of culm sheath $(\mathrm{r}=-0.842, \mathrm{P}<0.01)$. Internodal length has a positive correlation with total culm sheath length $(\mathrm{r}=0.868, \mathrm{P}<0.01)$ and a negative correlation with breadth at the base of the culm sheath $(\mathrm{r}=-0.666, \mathrm{P}<0.05)$. Total culm sheath length had a negative correlation with breadth at the base of the culm sheath $(\mathrm{r}=-0.664, \mathrm{P}<0.05)$ and positive correlation with total leaf length $(\mathrm{r}=0.787, \mathrm{P}<0.01)$.

\section{Principal coordinate analysis}

In a PCA with all samples, the first two axes explained 25.22 and $16.17 \%$, respectively, of the variation in the matrix and differentiated the accessions according to their genetic 
diversity and antioxidant activity (Figure 5). Geographically, genetic group 2 distributed in the same areas, i.e., different geographical sites of the Chandel district. Conversely, genetic Group 1, containing 4 accessions, is geographically isolated from the first ones and covers the cultivating areas of the Imphal-East district. Basically, all $D$. hamiltonii accessions of the same geographical location clustered in the same group. All 4 accessions that were grouped in the first cluster, possessing high antioxidant scavenging activity (43.45 to $36.9 \%$ ) were spatially isolated in the two dimensional PCOOR plots within 0.4 to 0.6 in dimension 1 and 0.06 to 0.08 in dimension 2. The other accessions that were grouped in the second cluster showed spatial distribution within 0 to -0.42 in dimension 1 and 0 to -0.7 in dimension 2 . The two major groups (Groups 1 and 2) revealed by UPGMA cluster analysis were confirmed by PCA. This analysis allowed discrimination between the accessions and established the relevance of the peaks to each principal coordinate, also substantiating their status in terms of antioxidant activity.

Table 5. Karl Pearson correlations for various morphological and biochemical parameters.

\begin{tabular}{|c|c|c|c|c|c|c|c|c|c|}
\hline Parameters & 1 & 2 & 3 & 4 & 5 & 6 & 7 & 8 & 9 \\
\hline 2 & $-0.980 * *$ & & & & & & & & \\
\hline 3 & -0.271 & 0.331 & & & & & & & \\
\hline 4 & -0.310 & 0.389 & $0.965 * *$ & & & & & & \\
\hline 5 & -0.374 & 0.348 & $0.831 * *$ & $0.732 *$ & & & & & \\
\hline 6 & -0.376 & 0.337 & $0.774 * *$ & $0.748^{*}$ & $0.868^{* *}$ & & & & \\
\hline 7 & -0.111 & -0.150 & $-0.829 * *$ & $-0.842^{* *}$ & $-0.666^{*}$ & $-0.664 *$ & & & \\
\hline 8 & -0.031 & 0.068 & -0.213 & -0.158 & -0.421 & -0.227 & -0.083 & & \\
\hline 9 & -0.164 & 0.081 & 0.554 & 0.526 & 0.559 & $0.787^{* *}$ & -0.594 & 0.007 & \\
\hline 10 & -0.002 & -0.093 & 0.133 & 0.061 & 0.368 & 0.396 & -0.475 & 0.364 & 0.434 \\
\hline
\end{tabular}

The Arabic numerals used represent the morphological and biochemical parameters for Karl Pearson correlations analysis as follows: $1=$ antioxidant activity (\%); $2=$ total cyanide content (ppm); $3=$ height of culm (m); $4=$ diameter $(\mathrm{cm}) ; 5=$ internodal length $(\mathrm{cm}) ; 6=$ total sheath length $(\mathrm{cm}) ; 7=$ breadth of culm sheath $(\mathrm{cm}) ; 8=$ imperfect blade length $(\mathrm{cm}) ; 9=$ total leaf length $(\mathrm{cm}) ; 10=$ leaf base $(\mathrm{cm}) . * \mathrm{P} \leq 0.05, * * \mathrm{P} \leq 0.01$.

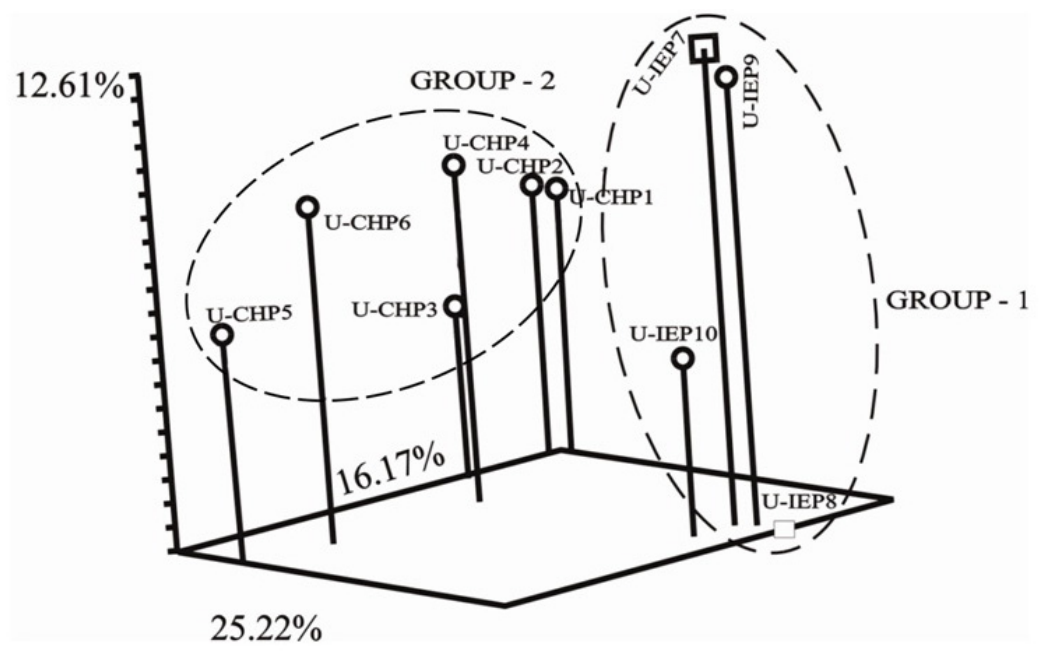

Figure 5. Principal coordinates analysis of 10 accessions of Dendrocalamus hamiltonii based on the data generated by AFLP markers. 


\section{Multiple regression analysis}

MRA was attempted to determine the association of AFLP markers with biochemical attributes, i.e., antioxidant activity of WEB and total cyanide content in different accessions of $D$. hamiltonii (Table 6). A total of 4 alleles generated by primers EcoRI-AAG(Joe)/ $M s e$ I-CTC, EcoRI-ACC(Ned)/MseI-CTG, EcoRI-AAC(Ned)/MseI-CTG, and EcoRIACG(Joe)/MseI-CAG showed positive correlation with antioxidant activity. Of these, the 273-bp peaks generated by EcoRI-AAG(Joe)/MseI-CTC showed a maximum (0.729) correlation with antioxidant activity, which was highly significant $(\mathrm{P}<0.01, \mathrm{t}=8.437)$. The regression coefficient $(\beta)$ was also very high $(0.860)$. Standard multiple regression can only accurately estimate the relationship between dependent and independent variables if the relationships are linear in nature. If the relationship between independent variables and the dependent variable is not linear, the results of the regression analysis will underestimate the true relationship. To ascertain the relationship between selected AFLP markers and antioxidant activity, markers selected at the first three consecutive steps of MRA were tested for the linear relationships with high antioxidant activity. It showed that the U-IEP8 accession with the highest antioxidant activity in bamboo shoot extract was in the range of 0.8 to 1.0 on the $\mathrm{x}$-axis and 10 to 15 on the y-axis for the AFLP markers (Figure 6). On the other hand, bamboo shoot extract of the U-IEP9, U-CHP2, U-CHP1, and U-CHP4 accessions with a moderate antioxidant activity occupied the central position at $0-0.2$ on the $\mathrm{x}$-axis and $-5-0$ on the y-axis. The other accessions with low antioxidant activity occupied the position in the negative range (both on the $\mathrm{x}$-axis and $\mathrm{y}$-axis) of the regression plot. Hence, the other AFLP markers generated by different primers can also be taken as markers for association with high antioxidant activity in bamboo shoots of $D$. hamiltonii and subsequent use for MAS (marker-assisted selection) in breeding programs.

\begin{tabular}{|c|c|c|c|c|c|c|c|c|c|c|}
\hline $\begin{array}{l}\text { Biochemical } \\
\text { parameters }\end{array}$ & Primer & $\begin{array}{c}\text { AFLP } \\
\text { markers } \\
\text { (alleles) }\end{array}$ & $\mathrm{r}$ & $\mathrm{R}^{2}$ & $\mathrm{R}^{2}$ change & F change & SE & $\begin{array}{l}\text { Standardized } \\
\text { coefficient } \beta\end{array}$ & $t$ value & $P$ value \\
\hline \multirow[t]{4}{*}{ Antioxidant activity } & EcoRI-AAG(Joe)/MseI-CTC & 273 & 0.729 & 0.961 & 0.961 & 19.966 & 1.578 & 0.860 & 8.437 & 0.000 \\
\hline & EcoRI-ACG(Joe)/MseI-CAG & 377 & 0.650 & 0.682 & 0.178 & 8.439 & 3.596 & 0.720 & 3.177 & 0.004 \\
\hline & EcoRI-AAC(Ned)/MseI-CTG & 396 & 0.670 & 0.879 & 0.879 & 16.028 & 2.499 & 0.811 & 5.093 & 0.000 \\
\hline & EcoRI-ACC(Ned)/MseI-CTG & 188 & 0.629 & 0.570 & 0.068 & 9.106 & 4.308 & 0.609 & 2.227 & 0.068 \\
\hline \multirow[t]{4}{*}{ Cyanide content } & EcoRI-AAG(Joe)/MseI-CTC & 273 & -0.664 & 0.678 & 0.678 & 4.215 & 41.710 & -0.742 & -3.159 & 0.001 \\
\hline & EcoRI-ACG(Joe)/MseI-CAG & 377 & -0.670 & 0.757 & 0.757 & 6.235 & 36.239 & -0.783 & -3.926 & 0.000 \\
\hline & EcoRI-AAC(Ned)/MseI-CTG & 396 & -0.694 & 0.780 & 0.213 & 7.099 & 34.475 & -0.762 & -3.798 & 0.000 \\
\hline & EcoRI-ACC(Ned)/MseI-CTG & 188 & -0.664 & 0.571 & 0.150 & 3.099 & 52.731 & -0.682 & -2.256 & 0.074 \\
\hline
\end{tabular}

In the case of total cyanide content, stepwise regression identified four alleles corresponding to 273, 377, 396, and 188 bp generated with the four primers EcoRI-AAG/MseICTC, EcoRI-ACG/MseI-CAG, EcoRI-AAC/MseI-CTG, and EcoRI-ACC/MseI-CTG, respectively. The standardized beta coefficient was in the negative range $(-0.682$ to -0.783$)$. The 396-bp peak generated by EcoRI-AAC(Ned)/MseI-CTG showed a negative correlation ( $\mathrm{r}=$ -0.694), which was significant $(\mathrm{P}<0.01, \mathrm{t}=-3.798)$. The association of the primer EcoRIACG(Joe)/MseI-CAG with the total cyanide content of the $10 \mathrm{D}$. hamiltonii accessions is shown in Figure 7. The linear relationships showed that U-IEP8, which possessed the lowest 
cyanide content in bamboo shoots occupied the range between 0.8 and 0 on the $\mathrm{x}$-axis and -150 and -100 on the $y$-axis. While the rest of the accessions of $D$. hamiltonii with the highest antioxidant activity in bamboo shoots occupied the range between -20 and 0 on the $\mathrm{x}$-axis and -50 and 50 on the y-axis.

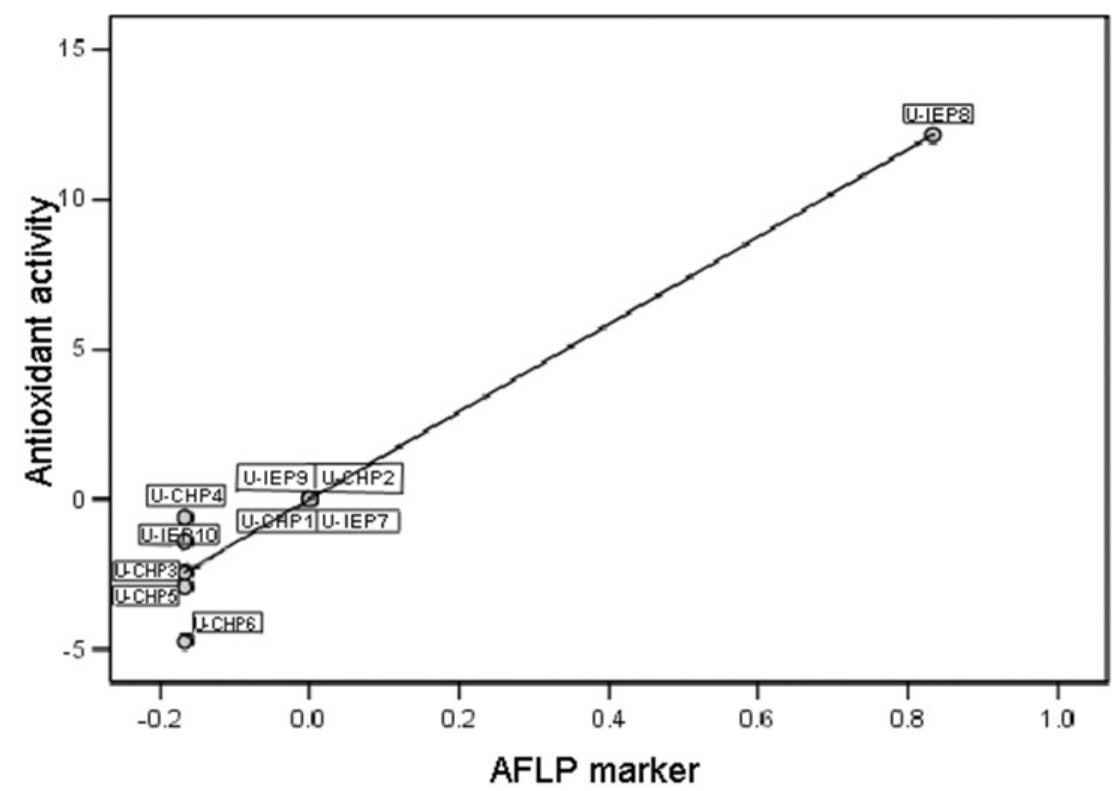

Figure 6. Regression plot for antioxidant activity with 273 bp generated by AFLP marker. The code names are for the accessions presented in Table 1 .

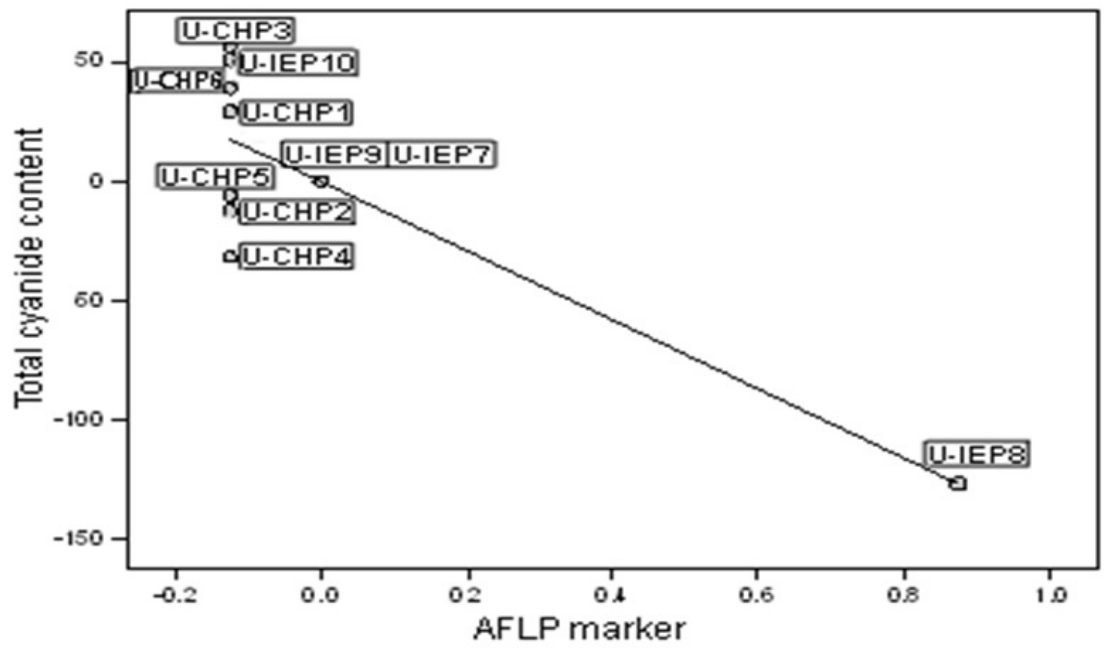

Figure 7. Regression plot for total cyanide content with 377 bp generated by AFLP marker. The code names are for the accessions presented in Table 1. 
The germplasm-regression-combined (GRC) marker-trait association identification has several advantages over the linkage-based identification of markers associated with genes/ QTLs (quantitative trait loci) because of the following reasons: i) this allows the detection of QTL that varies across a wide spectrum of biodiversity rather than just between two planned parental genotypes; ii) this requires less inputs of time, labor and financial resources, compared to linkage-based QTL identification, and iii) this technique plays an important role in plant MAS/QTL breeding programs, especially in orphan crops and long-juvenile woody plants with heterozygosity when no other genetic information such as linkage maps and QTL are available. Such studies of GRC analysis have also been carried out to identify the associations of molecular markers with desirable traits in various crops and woody plants with great success, such as Asian rice (Virk et al., 1996), tea (Mishra and Sen-Mandi, 2004), wheat (Roy et al., 2006), mulberry (Kar et al., 2008), and birch (Wang et al., 2008).

Hence, based on the AFLP markers associated with the biochemical traits, identified by MRA, the genotype U-IEP8 could be of great use itself as well as in MAS breeding programs for developing further superior genotypes of $D$. hamiltonii that have high antioxidant activity with low total cyanide content.

\section{ACKNOWLEDGMENTS}

S.D. Waikhom received a postdoctoral fellowship from the Department of Biotechnology, Government of India. We are thankful to Dr. Pushpa Kumari, Botanical Survey of India (BSI) for plant identification and herbarium support. S. Ghosh is grateful to ICMR for an ad hoc fellowship.

\section{REFERENCES}

Affifi AA and Clark V (1984). Computer-aided multivariate analysis. Van Nostrand Reinhold, New York.

Ballhorn DJ, Kautz S and Rakotoarivelo FP (2009). Quantitative variability of cyanogenesis in Cathariostachys madagascariensis - the main food plant of bamboo lemurs in Southeastern Madagascar. Am. J. Primatol. 71: 305-315.

Bhatt BP, Singh K and Singh A (2005a). Nutritional values of some commercial edible bamboo species of the North Eastern Himalayan region, India. J. Bamboo Rattan 4: 111-124.

Bhatt BP, Singha LB, Sachan MS and Singh K (2005b). Commercial edible bamboo species of the north eastern Himalayan region, India. Part II. Fermented, roasted and boiled bamboo shoots. J. Bamboo Rattan 4: 13-31.

Bhattacharya S, Das M, Bar R and Pal A (2006). Morphological and molecular characterization of Bambusa tulda with a note on flowering. Ann. Bot. 98: 529-535.

Connor MA, Finn CE and Alspach PA (2005). Genotypic and environmental variation in antioxidant activity and total phenolic content among blackberry and hybridberry cultivars. J. Am. Soc. Hort. Sci. 130: 527-533.

Dice LR (1945). Measures of the amount of ecologic association between species. Ecology 26: $297-302$.

Doyle JJ and Doyle JL (1990). Isolation of Plant DNA from fresh tissue. Focus 12: 13-15.

Drogoudi PD, Michailidis Z and Pantelidis G (2008). Peel and flesh antioxidant content and harvest quality characteristics of seven apple cultivars. Sci. Hortic. 115: 149-153.

Garcia AAF, Benchimol LL, Barbosa AMM, Geraldi IO, et al. (2004). Comparison of RAPD, RFLP, AFLP and SSR markers for diversity studies in tropical maize inbred lines. Genet. Mol. Biol. 27: 579-588.

Ghosh S, Devi SW, Sen Mandi S and Talukdar NC (2011). Amplified fragment length polymorphism based study of phylogenetic relationship and genetic variability among some edible Bamboo species of North-East India. J. Plant Mol. Biol. Biotechnol. 2: 8-15.

Haque MR and Bradbury JH (2002). Total cyanide determination of plants and foods using the picrate and acid hydrolysis methods. Food Chem. 77: 107-114.

Harborne JB (1993). Plant Toxins and Their Effects on Animals. In: Introduction to Ecological Biochemistry. Academic Press, London, 71-103. 
Hu C, Zhang Y and Kitts DD (2000). Evaluation of antioxidant and prooxidant activities of bamboo Phyllostachys nigra var. Henonis leaf extract in vitro. J. Agric. Food Chem. 48: 3170-3176.

Jeyaram K, Singh ThA, Romi W, Devi AR, et al. (2009). Traditional fermented foods of Manipur. Indian J. Tradit. Knowledge 8: 115-121.

Jones DA (1998). Why are so many food plants cyanogenic? Phytochemistry 47: 155-162.

Kar PK, Srivastava PP, Awasthi AK and Urs SR (2008). Genetic variability and association of ISSR markers with some biochemical traits in mulberry (Morus spp.) genetic resources available in India. Tree Genet. Genomes 4: 75-83.

Kweon MH, Hwang HJ and Sung HCh (2001). Identification and antioxidant activity of novel chlorogenic acid derivatives from bamboo (Phyllostachys deulis). J. Agric. Food Chem. 49: 4646-4655.

Lalhruaitluanga $\mathrm{H}$ and Prasad MNV (2009). Comparative results of RAPD and ISSR markers for genetic diversity assessment in Melocanna baccifera Roxb. growing in Mizoram State of India. Afr. J. Biotechnol. 8: 6053-6062.

Mensor LL, Menezes FS, Leitao GG, Reis AS, et al. (2001). Screening of Brazilian plant extracts for antioxidant activity by the use of DPPH free radical method. Phytother. Res. 15: 127-130.

Mishra RK and Sen-Mandi S (2004). Molecular profiling and development of DNA marker associated with drought tolerance in tea clones growing in Darjeeling. Curr. Sci. 87: 60-66.

Nirmala C, David E and Sharma ML (2007). Changes in nutrient components during ageing of emerging juvenile bamboo shoots. Int. J. Food Sci. Nutr. 58: 612-618.

Ohrnberger D and Goerrings J (1986). The Bamboos of the World. Elsevier Science, Odenthal.

Park E-J and Jhon D-Y (2010). The antioxidant, angiotensin converting enzyme inhibition activity, and phenolic compounds of bamboo shoot extracts. LWT-Food Sci. Techn. 43: 655-659.

Rohlf FJ (2000). NTSYS-pc numerical taxonomy and multivariate analysis system. Version 2.20e. Exeter Publication, New York.

Roy JK, Bandopadhyay R, Rustgi S, Balyan HS, et al. (2006). Association analysis of agronomically important traits using SSR, SAMPL and AFLP markers in bread wheat. Curr. Sci. 90: 683-689.

Ruan CJ, Li H and Mopper S (2009). Characterization and identification of ISSR markers associated with resistance to dried-shrink disease in sea buckthorn. Mol. Breed. 24: 255-268.

Sciacca F, Fichera C, Di Silvestro S, Conte E, et al. (2010). Genetic diversity of durum wheat as determined by AFLP in fluorescence. Biol. Plant. 54: 198-200.

Shi QT and Yang KS (1992). Study on relationship between nutrients in bamboo shoots and human health. Proceedings of the International Symposium on Industrial Use of Bamboo. International Tropical Timber Organization and Chinese Academy, Beijing, 338-346.

Sneath PHA and Sokal RR (1973). Numerical Taxonomy: The Principles and Practice of Numerical Classification. W.H. Freeman, San Francisco.

Sokal RR and Michener CD (1958). A statistical method for evaluating systematic relationships. Univ. Kans. Sci. Bull. 28: $1409-1438$.

Srivastava RC (1990). Bamboo: new raw materials for phytosterols. Curr. Sci. 59: 1333-1334.

Stapleton CMA (1994). The Bamboos of Nepal and Bhutan Part I: Bambusa, Dendrocalamus, Melocanna, Cephalostachyum, Teinostachyum, and Pseudostachyum (Gramineae: Poaceae, Bambusoideae) Edinb. J. Bot. 51: 1-32.

Vetter J (2000). Plant cyanogenic glycosides. Toxicon 38: 11-36.

Virk PS, Ford-Lloyd BV, Jackson MT, Pooni HS, et al. (1996). Predicting quantitative variation within rice germplasm using molecular markers. Heredity 76: 296-304.

Vos P, Hogers R, Bleeker M, Reijans M, et al. (1995). AFLP: a new technique for DNA fingerprinting. Nucleic Acids Res. 23: 4407-4414.

Wang D, Wei ZG, Yang CP and Liu GJ (2008). Analysis and identification of SCAR molecular markers associated with birch fiber length trait. J. For. Res. 19: 288-292.

Wu MCY (1962). Classification of Bambuseae based on leaf anatomy. Bot. Bull. Acad. Sin.3: 83-107. 